2014

\title{
Religious Diversity, Education, and the 'Crisis' in State Neutrality
}

Benjamin L. Berger

Osgoode Hall Law School of York University, bberger@osgoode.yorku.ca

Follow this and additional works at: http:// digitalcommons.osgoode.yorku.ca/olsrps

\section{Recommended Citation}

Berger, Benjamin L., "Religious Diversity, Education, and the 'Crisis' in State Neutrality" (2014). Osgoode Legal Studies Research Paper Series. 76.

http://digitalcommons.osgoode.yorku.ca/olsrps/76 


\section{OSGOODE HALL LAW SCHOOL LEGAL STUDIES RESEARCH PAPER SERIES}

Research Paper No. 62

Vol. 10/ Issue. 14/ (2014)

\section{Religious diversity, education, and the "crisis" in state neutrality}

Berger, B. Religious diversity, education, and the "crisis" in state neutrality. Canadian Journal of Law and Society, forthcoming.

Benjamin L. Berger

\section{Editors:}

Editor-in-Chief: Carys J. Craig (Associate Dean of Research \& Institutional Relations and Associate Professor, Osgoode Hall Law School, York University, Toronto)

Production Editor: James Singh (Osgoode Hall Law School, York University, Toronto)

This paper can be downloaded free of charge from:

http://ssrn.com/abstract $=2335837$

Further information and a collection of publications from the Osgoode Hall Law School Legal Studies Research Paper Series can be found at:

http://papers.ssrn.com/sol3/JELJOUR_Results.cfm?form_name=journalbrowse\&journal_id=722488 
Osgoode Legal Studies Research Paper No. 62

Vol. 10/ Issue. 14/ (2014)

\title{
Religious diversity, education, and the "crisis" in state neutrality
}

Berger, B. Religious diversity, education, and the "crisis" in state neutrality. Canadian Journal of Law and Society, forthcoming.

\section{Benjamin L. Berger}

\begin{abstract}
:
Education - and particularly public education - has become a crucible for the relationship between state and religious diversity, a principal site for contemporary debates about the meaning of secularism and the management of religious difference. This is so across a variety of national traditions, and despite wide differences in the historical and "emotional inheritances" surrounding the configuration of law, politics, and religion. Through an exploration of Hannah Arendt's thought about responsibility and freedom in education, this article works towards a better understanding of why education is such a crucial and fraught field in the modern encounter between religion and law. The article turns to the recent jurisprudence of the Supreme Court of Canada to draw out the implications of these ideas, arriving ultimately at a claim about the nature and limits of the concept of state neutrality.
\end{abstract}

\section{Keywords:}

Religion, Education, Law, Arendt, Neutrality, Toleration

\section{Author(s):}

Benjamin L. Berger

Associate Professor

Osgoode Hall Law School

York University, Toronto

E: bberger@osgoode.yorku.ca 


\title{
RELIGIOUS DiVERSITY, EDUCATION, AND THE “CRISIS” IN STATE NEUTRALITY
}

\author{
Benjamin L. Berger
}

The classroom has become a principal site for contemporary debates about the meaning of secularism and the management of religious difference. This is so across a variety of national traditions, and despite wide differences in the historical and "emotional inheritances" 1 surrounding the configuration of law, politics, and religion. In Italy, the Lautsi $v$ Italy $^{2}$ case challenged the historical privilege of Catholicism in Italy in the context of a modern, bureaucratized EU when the practice of hanging crucifixes in all public schools was put in question. Analogous questions concerning the presence of religious symbols in public schools have arisen in France, ${ }^{3}$ Turkey, ${ }^{4}$ and Germany. ${ }^{5}$ The case of $R(E) v$ Governing Body of JFS, ${ }^{6}$ in the U.K., raised the limits of religious community self-definition, asking whether a Jewish school had untrammelled authority to shape admissions policies that define who is and is not Jewish. Similar issues concerning the relationship between

\footnotetext{
*Associate Professor, Osgoode Hall Law School, York University. Many thanks to John Borrows, Lotem Perry-Hazzan, and Mariana Valverde for comments on earlier drafts of this article, and to Jenn Aubrey for conversations that have significantly influenced my thinking on many of these issues. Thanks also to Geneviève Murray and Madison Robins for their excellent research assistance and to the two anonymous peer reviewers for their helpful comments. The author wishes to acknowledge the financial support for this research provided by the Social Sciences and Humanities Research Council of Canada.

${ }^{1}$ This phrase, "emotional inheritances," is borrowed from Talal Asad, "French Secularism and the 'Islamic Veil Affair'," The Hegehog Review (2006).

${ }^{2}$ Lautsi and others v Italy, 19 March 2011, European Court of Human Rights (Grand Chamber), No. 30814/06.

${ }^{3}$ Talal Asad provides a rich and provocative discussion of the Stasi Commission and its place in recent debates about French secularism and national identity: "French Secularism and the 'Islamic Veil Affair'."

${ }^{4}$ See Leila Şahin v Turkey, 10 November 2005, European Court of Human Rights (Grand Chamber), No. 44774/98.

${ }^{5}$ Tobias Lock offers a helpful account of the recent history of religious symbols in German schools: Tobias Lock, "Of Crucifixes and Headscarves: Religious Symbols in German Schools," in Law, Relgious Freedoms, and Education in Europe, ed. Marie HunterHenin (London: Ashgate, 2012).
}

${ }^{6}$ [2009] UKSC 15. 
religious belonging and legal prohibitions on discrimination have arisen in Israel. ${ }^{7}$

In Canada, the education sphere has become the focal point - often a flashpoint - for debates about both the accommodation of religious difference and the challenges of civic belonging in conditions of religious diversity. This close tethering of issues of religious difference and education, as well as the use of religion as a site of accommodation and as a tool for assimilation, have a deep and rich pedigree in Canada. The political compromises between English and French Canada at the founding of the nation placed religious accommodation through education at the cornerstone of the state. The Treaty of Paris $(1763)^{8}$ and the Quebec Act (1774) $)^{9}$ offered a form of accommodation and toleration for Roman Catholicism to French inhabitants of what would eventually be Canada. These protections found their expression in the first Canadian constitution, the British North America Act (1867), ${ }^{10}$ in s. 93, a provision that guaranteed publicly funded Roman Catholic education outside of Quebec, and Protestant public education within majority-Catholic Quebec. Yet alongside this story of accommodation is also a history of the use of education to control and suppress cultural and religious difference. Residential schools were used by the state in a devastating assault on Aboriginal religion, language, and culture, employing state supported and religiously provided education in an attempt to violently assimilate the Indigenous peoples of Canada. The effects of this period, one of the darkest in Canadian history, are still felt today. ${ }^{11}$ And a journey into the religious history of British Columbia and Alberta offers up the case of the Doukhobors, whose religious beliefs led to violent clashes with the state over the education of children. ${ }^{12}$

\footnotetext{
${ }^{7}$ See, for example, Noar Kehalacha Association v Ministry of Education, (2009) IsrLR 84, HCJ 1067/08; Tebeka Advocacy for Equality \& Justice for Ethiopian-Israelis $v$ The ministry of Education (2010), HCJ 7426/08.

${ }^{8}$ Definitive Treaty of Peace, France, Great Britain, and Spain, 10 February 1763, 42 Cons TS 279.

${ }^{9}$ Quebec Act, 1774 (UK), 14 Geo III, c 83.

${ }^{10}$ Constitution Act, 1867 (UK), 30 \& 31 Vict, c 3, reprinted in RSC 1985, App II, No 5 (formerly British North America Act, 1867).

${ }^{11}$ See J. R. Miller, Shingwauk's Vision: A History of Native Residential Schools (Toronto: University of Toronto Press, 1996). For a recent statement from the Supreme Court of Canada on the effects of this experience, see $R v$ Ipeelee, [2012] 1 SCR 433.

${ }^{12}$ John P.S. McLaren, "The Doukhobor Belief in Individual Faith and Conscience and the Demands of the Secular State," in Religious Conscience, the State, and the Law: Historical Contexts and Contemporary Significance, ed. John McLaren and Harold Coward (Albany: State University of New York Press, 1999), 199.
} 
Yet this story of education as the terrain on which issues of religious difference and civic belonging has been played is not simply an interesting, if harrowing, history. Education has continued to be the arena that has yielded some of the fiercest and most perplexing challenges in the governance and accommodation of religious difference. Indeed, as the forms and intensity of religious difference in Canada have multiplied, so too have the cases in which conflicts between religious accommodation and the demands of public life have taken shape around questions of education. ${ }^{13}$ Shortly after the introduction of the Charter ${ }^{14}$ in 1982, the Supreme Court of Canada was asked to reconsider the privileging of statefunded Catholic education in Ontario - the fruit of that guarantee at Confederation found in s. 93 - in light of the existence of Jewish, Protestant, and other religious groups for whom faith- and culture-based education was equally important as a means of sustaining their communities. ${ }^{15}$ Although the Supreme Court declined to disrupt the results of this historical compromise, the issue remains a live political question. The law of religious freedom led to the secularization of public education, with traditional Christian symbols and practices draining from public schools. ${ }^{16}$ Legal conflicts between the rights of sexual minorities and those of religious groups have arisen principally in the field of education, with the Court having to rule on the extent to which religious viewpoints can inform a public school board's decision-making about representing same-sex parented families in Kindergarten-Grade 1 curriculum, ${ }^{17}$ whether publicly funded Catholic schools can exclude a male student's boyfriend from the prom, ${ }^{18}$ and whether a private Evangelical Christian religious university that has a code of conduct that discriminates against gay, lesbian, and queer students and faculty can have their teachers' training program publicly accredited. ${ }^{19}$ Through these

\footnotetext{
${ }^{13}$ For an account of some of the features that make religious accommodation and toleration particularly fraught and vexing in educational contexts, see Colin Macleod, "Toleration, Chidren and Education," Educational Philosophy and Theory 42, no. 1 (2010).

${ }^{14}$ Canadian Charter of Rights and Freedoms, Part I of the Constitution Act, 1982, being Schedule B to the Canada Act 1982 (UK), 1982, c 11.

${ }^{15}$ See Reference re Bill 30, An Act to Amend the Education Act (Ontario), [1987] 1 SCR 1148; Adler $v$ Ontario, [1996] 3 SCR 609.

${ }^{16}$ See Zylberberg $v$ Sudbury Board of Education (1988), 65 OR (2d) 641 (CA).

${ }^{17}$ See Chamberlain v Surrey School District No. 36, [2002] 4 SCR 710.

${ }^{18}$ See Hall v Powers (2002), 213 DLR (4th) 308.

${ }^{19}$ See Trinity Western University v British Columbia College of Teachers, [2001] 1 SCR 772. See also Richard Moon, "Sexual Orientation, Equality, and Religious Freedom in the Public Schools: A Comment on Trinity Western University v. B.C. College of Teachers and
} 
and many other cases, both the deeper and the modern histories of the legal management of religious diversity in Canada could be told quite ably through a story about education.

This article is an attempt to understand why education, and particularly public education, has been a crucible for the relationship between state and religious diversity. I will exploit a decision of the Supreme Court of Canada to explore why this is so and how issues of religious diversity are handled through law. Although my focus is on the Canadian example, my suspicion is that at least some of the lessons are more generalizable. And ultimately, though I enter the problem through the portal of education, I arrive at a set of claims about the nature of - and a key distinction within - the idea of state neutrality. I begin, however, with one provocative account of what is at stake in education.

\section{Natality, Responsibility, and the Stakes of Education}

In Between Past and Future, Hannah Arendt begins a chapter entitled "The Crisis in Education" by defending the idea that one could characterize a problem in American approaches to education as a "crisis" without engaging in rank hyperbole. ${ }^{20}$ Arendt concedes that, in view of the world-scale crises that afflicted humanity in the $20^{\text {th }}$ century, complaints about modern approaches to education might seem of trifling import. Yet she insists on the importance of her topic and the aptness of her label. The chapter is a kind of account of the grand social and philosophical stakes of education.

The problem that Arendt identified in her time was the ascendancy of a view of child education that embraced a certain constructivist pedagogy, one that insisted that teachers ought not to instruct or teach the children about the world directly but, rather, that good education inhered in facilitating the child's own discovery of the world. Teachers should step back, leave the world to the children to discover and construct autonomously. Arendt saw much politically and philosophically wrong with this approach. Indeed, she viewed it as a crisis of responsibility. Arendt argues that, through education, adults must take responsibility for the world as it is, must faithfully reflect, embody and hold it up to children, quite apart from their hopes about what that world might become:

Chamberlain v. Surrey School Board, District 36," Review of Constitutional Studies 8, no. 2 (2003).

${ }^{20}$ Hannah Arendt, "The Crisis in Education," in Between Past and Future: Eight Exercises in Political Thought (London: Penguin Books, [1968] 2006). 
educators here stand in relation to the young as representatives of a world for which they must assume responsibility although they themselves did not make it, and even though they may, secretly or openly, wish it were other than it is. This responsibility is not arbitrarily imposed upon educators; it is implicit in the fact that the young are introduced by adults into a continuously changing world. ${ }^{21}$

Why, for Arendt, is there this responsibility? Can more be said beyond the banal observation that what we teach our children is important?

The essence of education, Arendt argues, is the fact of natality: "the fact that we have all come into the world by being born and that this world is constantly renewed through birth". ${ }^{22}$ However revolutionary, however novel, however progressive the times into which a child is born, the world is old. It is "superannuated and close to destruction" ${ }^{23}$ And this fact of natality is what gives education its special mandate, its political essence:

Education is the point at which we decide whether we love the world enough to assume responsibility for it and by the same token save it from that ruin which, except for renewal, except for the coming of the new and young, would be inevitable. And education, too, is where we decide whether we love our children enough not to expel them from our world and leave them to their own devices, nor to strike from their hands the chance of undertaking something new, something unforeseen by us, but to prepare them in advance for the task of renewing a common world. ${ }^{24}$

There is much in this rich quotation that gestures to what is at stake in approaches to, and debates about, education.

First, Arendt emphasizes here that education is about the sustenance and continuance of social worlds. Education is where culture happens, it is where the old, otherwise consigned to fade, is refreshed and restored by new hands. Community is confirmed, renewed, and sustained through the faithful representation of the world to the "new ones." And so Arendt speaks of the way in which parents, through education, assume

\footnotetext{
${ }^{21}$ Ibid., at 186.

${ }^{22}$ Ibid., at 193.

${ }^{23}$ Ibid., at 189 .

${ }^{24}$ Ibid., at 193.
} 
responsibility "for the life and development of the child and for the continuance of the world". ${ }^{25}$ Because we love our worlds, through education we entrust their continuance and vitality to a new generation.

But Arendt's claim is ultimately one about political freedom, not just the transmission of culture and the continuance of social worlds. Were it only that, education could be solely a familial, private, or parochial matter. To be sure, Arendt sees the family as serving a potentially important role, one she links to the need that children have for privacy. She describes the family as the four walls that protect the child from the outside world: "These four walls, within which people's private family life is lived, constitute a shield against the world and specifically against the public aspect of the world". ${ }^{26}$ But the family is not the site of the responsibility that she has in mind. As much as the family can be a site of shelter, it can also be a place of unfreedom, repression, and - too often denial of the dignity of a safe and full existence. As Arendt herself notes, the responsibility assumed by parents for the continuance of their world can work at cross-purposes with their responsibility for the life and development of the child. The four walls are as apt to constrain as to protect. And it is here that we see Arendt's dominant theme emerge education as a condition for freedom:

Normally the child is first introduced to the world in school. Now school is by no means the world and must not pretend to be; it is rather the institution that we interpose between the private domain of home and the world in order to make the transition from the family to the world possible at all. Attendance there is required not by the family but by the state, that is by the public world, and so, in relation to the child, school in a sense represents the world, although it is not yet actually the world. ${ }^{27}$

Education is the bridge between family or community and "the world." It seeks to equip children with a picture of the world as they will find it. In so doing, education opens up new alternatives in their horizons of possibility for their lives, for ethical engagement with others, and for forms of a common world. Education gives children "the chance of

\footnotetext{
${ }^{25}$ Ibid., at 182.

${ }^{26}$ Ibid., at 183 .

${ }^{27}$ Ibid., at 185.
} 
undertaking something new, something unforeseen by us". ${ }^{28}$ Because we love our children, through education we equip them for freedom.

Education is about making and sustaining community; about shaping a creative, ethical actor in the world; it is perhaps one of the key pivot points between family and society; it is a site for preparation for the world as we now find it; and, in complex ways, it is a place for the cultivation and exercise of freedom.

This is what sits at the heart of conflicts and debates about religious diversity, the state, and education. These contests that take place within school settings are conversations about the world for which we are prepared to take responsibility. For religious groups and the state alike, education is the means by which culture, tradition, value and community are affirmed and sustained. Education is a political act concerned with inducing a child into a social world; in this, it is unapologetically conservative. This is, indeed, the appeal and importance of education to the state and to sub-national (including religious) communities alike. It is this reality that led to the provision for religious schools as the key protection for French culture at the founding of Canada. This is one facet of education - the transmission of social worlds. Yet, as Arendt stresses, education is also about providing the conditions for the ethical exercise of freedom, with the possibilities and uncertainties - the potential for the truly new - that this entails. This is the complex frame in which cases about religion and education must be read.

\section{SL v Commission scolaire des Chênes}

It is with these ideas in mind that I now examine a recent case decided by the Supreme Court of Canada, SL $v$ Commission scolaire des Chênes. ${ }^{29}$ The case raised the question of whether parents may exempt their children from classes designed to expose them to a variety of religious traditions and to the history of religion in Quebec. The decision discloses much about recent shifts in the terrain of religion and secularism in Canada, and does so in a context that interestingly activates the concerns and stakes that I have thus far explored.

To appreciate the case fully, the $S L$ decision must be placed on two interesting trajectories in the interaction of law and religion in Canada. The first is a shift in the types of concerns reflected in law and religion cases. One might say that early in the jurisprudence under the Charter, the dominant theme in the religious freedom cases at the Supreme Court of

\footnotetext{
${ }^{28}$ Ibid., at 193. See Mordechai Gordon, "Hannah Arendt on Authority: Conservatism in Education Reconsidered," Educational Theory 49, no. 2 (1999): 172.

${ }^{29}$ [2012] 1 SCR 235.
} 
Canada was the disembedding of Christian privilege. The first freedom of religion case heard by the Supreme Court under the Charter, and the case that set the path for the development of the jurisprudence in this area, was $R v$ Big M Drug Mart. ${ }^{30}$ The case turned on whether common Sunday day of rest imposed under legislation entitled The Lord's Day Act was consistent with principles of religious liberty. In finding that the legislation was irredeemably tainted by its facial endorsement of religion, contrary to the right to be free from state-imposed religion, Justice Dickson (as he then was) explained the mischief of the legislation as follows:

To the extent that it binds all to a sectarian Christian ideal, the Lord's Day Act works a form of coercion inimical to the spirit of the Charter and the dignity of all nonChristians....The theological content of the legislation remains as a subtle and constant reminder to religious minorities within the country of their differences with, and alienation from, the dominant religious culture. ${ }^{31}$

Thus, the early tone of the jurisprudence under the Charter was one that sounded in the register of the pluralistic demands of a secular society. This and other early decisions were frequently about unseating Christianity's privileged place next to state institutions and in political life. This tone was also present in the field of education, with early cases famously concerning themselves with stripping away the artefacts of Christian historical privilege in public schools. In Zylberberg $v$ Sudbury Board of Education, ${ }^{32}$ the Ontario Court of Appeal ruled unconstitutional a local regulation that required that public school days begin or end with the recitation of the Lord's Prayer, a practice that had subsisted in many Canadian public schools since early in the life of the country. Drawing inspiration from Justice Dickson's reasons in Big M, the Ontario Court of Appeal held that this practice served to inculcate Christianity among public school pupils and was inconsistent with the multicultural reality of modern Canada. Provisions allowing for children to be exempted from the practice could not cure the problem. This 1988 decision sits interestingly alongside similar issues that have emerged more recently in Turkey, France, Germany, and elsewhere in Europe.

The examples could be multiplied. The key point is that in many of the early cases, freedom of religion was really about evenhandedness as

\footnotetext{
${ }^{30} \mathrm{R} v$ Big M Drug Mart, [1985] 1 SCR 295.

${ }^{31}$ Ibid., at 337.

${ }^{32}$ Supra note 16.
} 
amongst religious and non-religious creeds, freedom from state-enforced religious practices or norms, and, in particular, disrupting the structural hegemony of Christianity. Over the next 20 years, the varieties of cases on religion pluralized, but the jurisprudence on freedom of religion remained comparatively underdeveloped within the package of Charter rights. The interesting inversion reflected in the $S L$ decision came during a renaissance in the law of religious freedom in the last 10 years. On one interpretation of the recent cases, issues of religious freedom have ceased being dominantly about freedom from religion, ${ }^{33}$ and have become about religious groups seeking exemptions from, or to push back on, a secular or non-religious default environment. Many of these cases have been about the appearance of religious symbols in public spaces. ${ }^{34}$ Such cases have also penetrated the education setting, with an important decision in recent Canadian jurisprudence on religious accommodation concerning the ability of a Sikh youngster to wear a kirpan, or religious dagger, in public school. ${ }^{35}$ Most relevant to this article is a meaningful subset of these cases in which religious schools or religious individuals involved in public schools have sought to resist substantive curricular or normative principles using arguments based in religious freedom.

One such case is Hall $v$ Powers, ${ }^{36}$ in which a Roman Catholic school refused to allow a gay student to bring his boyfriend to the high school prom. The student sought an interim injunction forcing the school to allow him and his boyfriend to attend. Despite the fact that this was a Roman Catholic school, the Court was sympathetic and issued the injunction. In the same year, the Supreme Court of Canada considered the case of Chamberlain v Surrey School District No. $36 .{ }^{37}$ Although not squarely a Charter case, Chamberlain was an important point in the recent Canadian jurisprudence on religion and secularism. The case involved a local public school board that, on the basis of the religious views of the parents in the constituency, had prohibited the use of resources depicting same-sex parented families in Kindergarten/Grade 1 classes. The Supreme Court

\footnotetext{
${ }^{33}$ With its unique history of state-church relations, reflected in the historical sketch provided earlier in this article, Canada has never adopted the strict institutional separationism found in U.S. constitutional law, nor has it endorsed the laïc approach found in France. Nevertheless, early in the Charter jurisprudence, Canadian courts recognized that freedom of religion implies freedom from religion, in the sense of freedom from coercion or compulsion in matters of religion.

${ }^{34}$ See, e.g., Rosenberg $v$ Outremont (City), [2001] RJQ 1556 (SC), concerning the eruv, or Syndicat Northcrest $v$ Amselem [2004] 2 SCR 551, concerning the sukkah on a balcony.

${ }^{35}$ See Multani v Commission scolaire Marguerite-Bourgeoys, [2006] 1 SCR 256.

${ }^{36}$ Supra note 18.

${ }^{37}$ Supra note 17.
} 
referred to the secular nature of public schools, as explicitly mandated by the governing legislation, and held that the decision of the school board was unreasonable because it had failed to give weight to secular principles of anti-discrimination, equality, and diversity. One further example, though one in which the religious community was successful in pushing back on secular norms, is Trinity Western University $v$ British Columbia College of Teachers. ${ }^{38}$ The case involved a college of teachers that had denied public accreditation to the teacher's program of an Evangelical Christian university on the grounds that the University required agreement to a code of conduct that discriminated against homosexual students and faculty. Trinity Western University successfully challenged the College's decision. The Supreme Court of Canada ruled that it was improper for the College to predict the future conduct of teachers trained at TWU on the basis of the code of conduct that they had signed.

Recent cases invert the early problematic. Less concerned with using the law to cleanse schools of religious traces, litigants are now deploying the logic of freedom of religion to resist a felt hegemony of secular ideals. Freedom from religion undergoes a subtle shift to freedom from the secular. SL sits at the high-water mark of this fascinating inversion, the first frame of context for the case.

The second arc of historical development in which the SL decision participates - again, at a kind of zenith of the trend - is more particular to the distinctive religious and social history of Quebec. In the latter half of the $20^{\text {th }}$ century, Canada experienced a profound diversification of cultures within its populace. This increased pluralism eventually led to a Canadian approach of multiculturalism, and, in 1971, the adoption of multiculturalism as official state policy. The period also saw an increasing endorsement of human rights instruments, culminating in the entrenchment of the Canadian Charter of Rights and Freedoms. While these trends were affecting all of Canada, Quebec was undergoing another profound change. Of course, in the origins of the country, Quebec's autonomy and identity were closely tied to Catholicism and the church. Over the 1960s, a set of rapid and intense social changes in Quebec - the so-called "Quiet Revolution" - transformed the society. Although there were other social and political changes associated with the quiet revolution, of most relevance to this article was the radical erosion of the power of the Roman Catholic Church in Quebec and the dramatic decoupling of secular politics and religious authority. Just as it had been crucial to the constitutional history of Catholicism in Canada, education was also central to the shifts of the Quiet Revolution. In 1964 the Quebec government took control over public education, something that had been

${ }^{38}$ [2001] 1 SCR 772. 
largely carried out by Catholic organizations before that time. This began a process that would culminate, three decades later, in the end of denominational school boards in Quebec and the removal of Quebec from the education provisions of s. 93 of the Constitution Act, 1867.

The $S L$ case was a response to the most recent move in this 50-year process of the disentanglement of religion and education in Quebec. In 2005 the Quebec government elected to replace all remaining Catholic and Protestant programs of religious instruction with a compulsory common education program for all public schools, entitled the "Ethics and Religious Culture Course" (ERC). Schools were no longer denominational by this time, but students frequently received some form of religious instruction within their public educations. The ERC would end such instruction, replacing it with a program that would teach about varieties of ethical and cultural frameworks within Quebec and would instruct about a range of religious traditions, as well as on the history of religion in Quebec. The preamble to the program, as it relates to religion, states as follows:

Instruction in religious culture, for its part, is aimed at fostering an understanding of several religious traditions whose influence has been felt and is still felt in our society today. In this regard, emphasis will be placed on Québec's religious heritage. The historical and cultural importance of Catholicism and Protestantism will be given particular prominence. The goal is neither to accompany students in a spiritual quest, nor to present the history of doctrines and religions, nor to promote some new common religious doctrine aimed at replacing specific beliefs. ${ }^{39}$

The purpose of the course was to prepare children for life in a pluralistic society, to educate them in the range of religious traditions that they might encounter, and to teach them about the religious heritage of Quebec. In 1997, when the first steps towards this new curriculum were being taken, the Quebec Minister of Education justified this move in the following way:

The social and religious landscape is shifting in all regions of Quebec. Public schools must respect the free choice or the free refusal of religion.... All schools must teach students to respect different allegiances. However, our schools must not altogether dismiss religious education. They must show that

${ }^{39} S L$, at para 34. 
they are open and able to recognize, regardless of specific convictions and from a critical point of view, the contribution made by the different religions in terms of culture, values and humanism....

....in the context of a pluralistic society, is it not desirable that all students receive some instruction concerning the phenomenon of religion, courses on religious culture which cover the various great traditions, and courses on the history of religion $?^{40}$

In 2008, the ERC became mandatory for all students in Quebec.

In May of that year, S.L. and D.J., Roman Catholic parents of two school-aged children in Quebec requested an exemption from the ERC for their children on the basis that this program infringed their and their children's freedom of conscience and religion. The heart of their position was that the ERC interfered with their ability to pass on Roman Catholicism to their children because it purported to teach about Catholicism in a neutral way alongside a number of other religions. Such an approach would inculcate a kind of relativism, the parents claimed, whereas they sought to instill in their children a commitment to the truth of the Catholic creed. The ministry refused their request in two separate decisions, decisions that were confirmed by the Superior Court and the Court of Appeal. On appeal to the Supreme Court of Canada, the central question was whether mandatory exposure to the ERC in public schools offended religious freedom. ${ }^{41}$

The Supreme Court dismissed the appeal. The crux of its decision was that the applicant parents had failed to discharge their burden of showing precisely how the ERC would interfere with their sincerely held commitment (and their right) to pass on their religion to their children. It is important to observe - and the majority and separate concurring decisions at the Supreme Court of Canada emphasize - that, having initiated the case so shortly after the ERC came into effect, there was no evidence as to how the course was actually delivered in public schools. Both the majority and minority decisions suggest that if it turned out that the ERC were implemented in a way that was disparaging or dismissive

\footnotetext{
${ }^{40}$ Ibid., at paras 13 and 14 .

${ }^{41}$ The case of Québec (Procureur general) c Loyola High School, 2012 QCCA 2139, raises an associated and potentially even more fraught issue - whether private religious schools must teach the ERC as prescribed by the ministry, or whether they can deliver a faithinflected version of the course. At the time of writing, application for leave to appeal to the Supreme Court of Canada had been submitted.
} 
of religion, the issue might well look different. But, so long as such instruction does not denigrate or promote one or another conception of religion, the mere fact of instructing children on various religious, ethical, and cultural systems, as well as on religious history in Quebec, did not interfere with the parents' religious freedom. For the Court, the magic lies in the concept of "indoctrination", which is the legal limit on the state's capacity to instruct on religion. The Court rejects the proposition that "exposing children to 'a comprehensive presentation of various religions without forcing the children to join them' constitutes in itself an indoctrination of students that would infringe the appellants' freedom of religion". ${ }^{42}$ Parents could continue to instruct their children on Catholicism as they saw fit at home.

The parents further argued that instruction on a variety of religious traditions without any clear position being transmitted - and, presumably, in dissonance with what is being taught at home - produces confusion in the child. The Court's reasoning in rejecting this argument is revealing in light of the themes of this article. Justice Deschamps writes as follows:

Parents are free to pass their personal beliefs on to their children if they so wish. However, the early exposure of children to realities that differ from those in their immediate family environment is a fact of life in society. The suggestion that exposing children to a variety of religious facts in itself infringes their religious freedom or that of their parents amounts to a rejection of the multicultural reality of Canadian society and ignores the Quebec government's obligations with regard to public education. Although such exposure can be a source of friction, it does not in itself constitute an infringement of s. 2(a) of the Canadian Charter and of s. 3 of the Quebec Charter. ${ }^{43}$

The Court expresses confidence in children's capacity to hold together multiple messages in the mix of education that they receive from their

\footnotetext{
${ }^{42} S L$, at para 37. The $S L$ cases mirrors many of the issues in the U.S. case of Mozert $v$ Hawkins County Bd of Education, 827 F2d 1058 (6th Cir 1987) and the Court's conclusion parallel the result in Mozert. Wisconsin v Yoder, 406 US 205 (1971), is, of course, another famous US case on religious objections to education, though it raises somewhat different issues. The Supreme Court of the United States ruled in favor of the Amish parents who objected to education beyond the $8^{\text {th }}$ grade. For a defence of the "Liberal Civic Education" based in a reaction to Mozert and Rawlsian political liberalism, see Stephen Macedo, "Liberal Civic Education and Religious Fundamentalism: The Case of God v. John Rawls?," Ethics 105, no. 3 (1995).

${ }^{43} S L$, at para 40.
} 
parents and from the school. But Justice Deschamps goes further. She suggests that the state might have a duty to expose children to a variety of religious and cultural "facts" around them, reasoning that the "multicultural reality of Canada" imposes certain obligations on the state regarding education. So long as the message remains "neutral" (a matter to which I will return below), to deny the Quebec government the ability to teach such a course to all children would be to disregard this obligation.

The decision is not terribly consequential as a matter of legal doctrine, turning as it did on an evidentiary point: given the early stage of the implementation of the ERC, the applicants were not able to adduce evidence that the course was being taught in a way that interfered with their ability to educate their children consistent with Roman Catholicism. Should such evidence emerge, the case might resolve differently. A general education in a range of religious traditions and in the social and political history of religion did not, in itself, amount to secular indoctrination, as the parents suggested. The case nevertheless offers much for understanding why the field of education is such a persistent flashpoint around the world for issues of religion and secularism.

The Court's use of the concept of indoctrination is where I want to join this decision with the broader ideas and themes evoked in the discussion of Arendt's views on education. Specifically, I want to question and qualify the Court's claim that this course is not a form of indoctrination. All education is, in a sense, a project of indoctrination. Education is a means of inducing a child into a world. It is about culture and, to exploit the etymology of the term, the cultivation of a certain kind of subject. Education is an opportunity for the transmission of tradition and history, and for the necessary preparation of children for the task of renewing and sustaining community. This was Arendt's first insight. ${ }^{44}$ It goes some distance in helping to appreciate the stakes of such disputes, and to understand the passion and persistence of questions of education in the meeting of religion and state authority.

The history of confederation, the experience of Aboriginal peoples, and the activism of Jewish and other religious communities around issues of education in Canada all point to the depth of communities' interest in education. In Adler ${ }^{45}$ a case in which non-Catholic parents argued that the funding of Catholic and public schools in accordance with s. 93 of the Constitution Act, 1867, but not other religious schools, breached their equality and religious freedom rights, Justice L'Heureux-Dubé supported

\footnotetext{
${ }^{44}$ See also Michael W. Apple, Ideology and Curriculum, 2nd ed. (New York: Routledge, 1990); Samuel Bowles and Herbert Gintis, Schooling in Capitalist America: Educational Reform and the Contradictions of Economic Life (New York: Basic Books, 1976).

${ }^{45}$ Adler, supra note 15.
} 
her position that the state should be required to provide funding to these groups in the following terms:

At issue here are the efforts of small, insular religious minority communities seeking to survive in a large, secular society.... we cannot imagine a deeper scar being inflicted on a more insular group by the denial of a more fundamental interest; it is the very survival of these communities which is threatened. ${ }^{46}$

It is for this reason that governments have continued to learn, as the example of the Doukhobors taught in Canada, that cultural communities will struggle - politically and, if necessary, physically - over issues of education. What is at stake in education is the future and vitality of the group itself, the continuation of a social world.

The more difficult question from a liberal political position is whether the state has a legitimate claim to the formation of its citizens. May it use education as a means of shaping children, of inducing them into the world as we have it? Viewed from some perspectives, this kind of self-conscious citizen formation on the part of the state may seem to have a certain illiberal quality to it; to be sure, allowing the state to occupy all corners of the landscape of education - public and private - and to crowd out community, family, and religious interests in the formation of the child would be both unwise and repressive. Yet with deep pluralism and secularism (understood in some fashion) ${ }^{47}$ as important political facts about our world, a central role for the state in citizen formation seems an irreducible public function. A pluralist democracy depends on the capacity of citizens to engage in thoughtful and inclusive forms of

\footnotetext{
${ }^{46}$ Ibid., at para 86 .

${ }^{47}$ Recent literature has emphasized the broad range of configurations of religion, politics, and law that can subsist under the label "secular." Some are moved to insist on the pluralisation of the term, referring instead to "secularisms;" others claim that there is nevertheless something that links these various manifestations of the secular together. This piece does not directly join this debate about the meaning of the term "secular," though debates about religion education and the nature of claims for state neutrality are part of wrestling with the concept and implications of secularism. For thoughtful discussions of the idea of "secularism," see e.g. Asad, "French Secularism and the 'Islamic Veil Affair'."; Mayanthi L. Fernando, "Reconfiguring Freedom: Muslim Piety and the Limits of Secular Law and Public Discourse in France," American Ethnologist 37, no. 1 (2010); James Q. Whitman, "Separating Church and State: The Atlantic Divide," Historical Reflections 34, no. 3 (2008); Janet R. Jakobsen and Ann Pellegrini, eds., Secularisms (Durham and London: Duke University Press, 2008); Michael Warner, Jonathan VanAntwerpen, and Crag Calhoun, eds., Varieties of Secularism in a Secular Age (Cambridge and London: Harvard University Press, 2010).
} 
deliberation amidst - and enriched by - substantial divergence in lifestyles and worldviews. As Taylor and Maclure emphasize, "[p]eaceful coexistence in a diverse society requires that we learn to find normal a range of identity-related differences." ${ }^{48}$ Intercultural knowledge, habits of tolerance, and respectful interaction across difference now appear to be civic skills comparable in importance to basic knowledge in math and science. ${ }^{49}$ In equipping children with these skills through primary and secondary education, the state is preparing them to discharge the burdens of responsible participation in a pluralist democracy, one in which they will have the opportunity to interact, collaborate, and constructively disagree with those who hold beliefs and live modes of life that differ from and challenge their own. Moreover, education about difference serves the principle of respect for autonomy, a commitment that underwrites fundamental rights and freedoms and on which the functioning of our democratic institutions depends. Such exposure to diversity is an expression of regard for, and an aspect of the cultivation of, the developing autonomy of children. As Colin Macleod explains, "development of the contemplative aspect of autonomy involves ensuring that children learn about, understand, and even have a kind of appreciation of the plurality of ends and perspectives that are present in a diverse society." ${ }^{50}$

This kind of education may well "make the task more difficult for parents seeking to transmit a particular order of beliefs to their children and even more difficult for groups wishing to shield themselves from the influence of the larger society;" ${ }^{151}$ it is nevertheless essential to cultivating

\footnotetext{
${ }^{48}$ Jocelyn Maclure and Charles Taylor, Secularism and Freedom of Conscience (Cambridge, Mass; London: Harvard University Press, 2011) 47.

${ }^{49}$ In Israel, society is facing a social crisis brought about by the failure to properly balance the needs of public education and claims of religious freedom. Substantial portions of the male ultra-Orthodox community are not being equipped with basic knowledge in fields such as English and math, creating tremendous barriers to employment and postsecondary education in this rapidly growing demographic. See Yoel Finkelman, "UltraOrthodox/ Haredi Education," in International Handbook of Jewish Education, ed. Helena Miller, Lisa Grant, and Alex Pomson, International Handbooks of Religion and Education (Springer Netherlands, 2011); Eli Berman, "Sect, Subsidy, and Sacrifice: An Economist's View of Ultra-Orthodox Jews," The Quarterly Journal of Economics 115, no. 3 (2000); Maayan Lubell, "Israeli Education: A State Divided," Chicago Tribune, 2012 Jan 01 2012; Amnon Rubinstein, "Give Haredi Children Tools for Life," Jerusalem Post, 2007 Sep 05 2007. For a case addressing the challenge of imposing a "core curriculum" on ultraOrthodox schools, see The Center for Jewish Pluralism v The Ministry of Eduction (2008), HCJ $4805 / 07$.

${ }^{50}$ Macleod, "Toleration, Chidren and Education," 17.

${ }^{51}$ Maclure and Taylor, Secularism and Freedom of Conscience: 16. See also Macleod, "Toleration, Chidren and Education," 13.
} 
the child's own capacity for critical and sensitive engagement with local, national, and global issues. ${ }^{52}$ Indeed, in its majority decision in Chamberlain $v$ Surrey School District No. 36, ${ }^{53}$ the Court affirmed the legitimacy of such a role for public education. While recognizing the strong interest that parents have in their children's education, and the importance of parental involvement, Chief Justice McLachlin emphasized that "[p]arental views, however important, cannot override the imperative placed upon the British Columbia public schools to mirror the diversity of the community and teach tolerance and understanding of difference" ${ }^{54}$ "Schools," the Court held in TWU, "are meant to develop civic virtue and responsible citizenship". ${ }^{55}$ Recall Arendt's claim that school serves the important role of introducing the child to the world, that it "represents the world," and that it is "the institution that we interpose between the private domain of home and the world in order to make the transition from the family to the world possible at all." 56 When that world is, factually, one of competing claims of truth, of religious diversity, of sexual diversity, of rich cultural difference, there is a strong case to be made that the state has a responsibility to equip the child for this transition between community or family and the broader world, for the sake of that common world that they are all tasked with renewing. ${ }^{57}$ In the words of the UN Convention on the Rights of the Child, education should be directed to "the preparation of the child for responsible life in a free society".$^{58}$

One might object that to call this kind of state undertaking "indoctrination" is to misuse the label: a key feature of indoctrination, properly identified, is that its goal is to contain and limit options and alternatives contemplated by the subject. State education in Canada, as I

\footnotetext{
${ }^{52}$ See Maclure and Taylor, Secularism and Freedom of Conscience: 102-3.

${ }^{53}$ [2002] 4 SCR 710.

${ }^{54}$ Chamberlain, at para 33.

${ }^{55} \mathrm{TWU}$, at para 13.

${ }^{56}$ Arendt, supra note 20 at 185; see above at note 27.

${ }^{57}$ The issue of who is best equipped to actually teach the content in something like a religious cultures course - a point not addressed in $S L$ - is a separate, but important, point. It may well be that the wisest course of action, in terms of both expertise and buyin, would be to involve the community in delivering this aspect of a curriculum. The Loyola case, supra note 41, poses the related question of whether there can be variation amongst religious and public schools in how the ERC could be delivered. Although that issue would demand its own careful analysis, I would be skeptical of a position that would imply that there is only one way to effectively teach intercultural knowledge and respectful engagement across difference.
}

${ }^{58}$ Convention on the Rights of the Child, 20 November 1989, 1577 UNTS 3, Can TS 1992 No 3, Article 29, section 1(d). 
have described it, is not engaged in that kind of horizon-limiting project. This refinement is welcome because it specifies a condition of any claim that the state has to citizen formation. Such a claim by the state is justified owing to education's function in opening up horizons of possibility for the child, nourishing that individual's capacity for critical reflection, and serving as an open, traversable portal between world and family. The political activity of education is justifiable to the extent that it plays the role that Arendt imagines (her second, crucial, point) - that it conduces to the child's freedom. Important limitations and caveats on the state's use of education in citizen formation flow from that principle. First, such education must proceed with respect and appreciation for the traditions, ways, and beliefs found at home or in communities. Family and religious community can be rich sources of nourishment and meaning; they are often - though not always - the raw material for children's self-definition and the exercise of their autonomy. ${ }^{59}$ Nothing about enlarging awareness of difference, cultivating skills of responsible citizenship, and facilitating a child's free authorship of their lives commands or justifies estrangement from these substantial resources. Secondly, to endorse one religion or to disparage a non-harmful religious practice or tradition is inconsistent with these objectives. ${ }^{60}$ The purpose of such education is not to take positions on or to impose a "particular conception of the good life". ${ }^{61}$ Insistence on this posture - let us call it a posture of neutrality - is crucial, as is recognition of the legitimate claim that states share with parents and communities over the formation of the child.

Some will immediately object that the priority given to freedom, self-authorship, and respect for difference, as well as the challenges that such education may pose for some parents and communities, is inconsistent with any such claim of neutrality. With this, consideration of $S L$ and the stakes of education brings us to a significant conceptual point about what it is that we ask of the state in the management of religious diversity, the point on which I wish to conclude this article.

\footnotetext{
${ }^{59}$ See Macleod, "Toleration, Chidren and Education," 16.

${ }^{60}$ Reference to the UN Convention on the Rights of the Child, supra note 58 , is instructive here. Article 29 states that education is to be directed to the child's self-fulfillment; respect for human rights, tolerance, equality, and the environment; and generally to "preparation of the child for responsible life in a free society" (section $1(a, b, d, e)$ ). Yet section 1(c) also affirms a commitment to "the development of respect for the child's parents, his or her own cultural identity, language and values" alongside "the national values of the country in which the child is living, the country from which he or she may originate, and for civilizations different from his or her own".

${ }^{61}$ Maclure and Taylor, Secularism and Freedom of Conscience: 103.
} 


\section{The Idea of State Neutrality}

A notable feature of the Supreme Court's decision in SL is the centrality of "state neutrality" as the governing principle for analyzing problems of religious diversity. Both the majority decision and the separate concurring decision, written by Justice LeBel, cite neutrality as the conceptual touchstone for the modern secular state. Justice Deschamps, for the majority, explains that " $\mathrm{t}]$ he concept of state religious neutrality in Canadian case law has developed alongside a growing sensitivity to the multicultural makeup of Canada and the protection of minorities" ${ }^{\prime 2}$ and Justice LeBel specifically notes that the Supreme Court has consistently "stressed the importance of neutrality in the public school system". ${ }^{63}$ Apart from the evidentiary ruling that leads the Court to dismiss the claim, the preoccupation of the Court in $S L$ is to affirm a commitment to a legal standard of state neutrality in response to the parents' contention that the ERC was not a neutral curricular offering. At one fascinating point in the judgment, Justice Deschamps grants that perfect state neutrality might not be possible from a philosophical standpoint. In so doing, she opens space for what I think must be conceded - that a course on various religious cultures, such as the ERC, may not be received by religious parents or communities as an entirely neutral phenomenon. ${ }^{64}$ But with a quick "be that as it may," the Court backs away from this finer philosophical point, taking comfort in the notion of state neutrality as a workable legal construct and rehearsing the legal genealogy of state neutrality in Canada. In effect, the Court's response is to affirm that the case is about state neutrality, to endorse that concept and its centrality, but to simply deny that a breach of this controlling principle has occurred.

The place given by the Supreme Court of Canada in SL to state neutrality as the organizing principle in matters of religious diversity reflects something interesting about the history of ideas regarding the intersection of religion and the state. Toleration, so crucial to early political thought about religious difference, retains an important role in contemporary political and legal discussion about religion, signaling a need for an ethic of respect and practices of accommodation in matters of

\footnotetext{
${ }^{62} S L$, at para 21.

${ }^{63}$ Ibid., at para 54.

${ }^{64}$ Ibid., at para 31. Arif A. Jamal and Farid Panjwani interestingly argue that a kind of objectification of religion - including the sort of propensity to relativism about which the parents in the SL case complained - is intrinsic to the curricularization of religion.

"Having Faith in Our Schools: Struggling with Definitions of Religion," in Law, Relgious Freedoms, and Education in Europe, ed. Marie Hunter-Henin (London: Ashgate, 2012), 79.
} 
religious difference. ${ }^{65}$ Nevertheless, one can discern a shift in emphasis from language of "toleration" to that of "neutrality." Judged on the basis of recent court rulings from a variety of courts around the world, one might well conclude that the concept of state neutrality has succeeded toleration as the guiding virtue in the legal treatment of religious difference. ${ }^{66}$ As the Supreme Court of Canada itself notes, "religious neutrality is now seen by many Western states as a [the?] legitimate means of creating a free space in which citizens of various beliefs can exercise their individual rights" ${ }^{67}$

The concepts of toleration and neutrality are frequently invoked together, but, in fact, they paint quite different pictures of the dynamics involved in law's response to religious difference. While calling for a certain ethic of respect and commitment to pluralism, toleration nevertheless conserves and confirms relations of power in its structural assumption of a "tolerator" and a "tolerated" ${ }^{68} \mathrm{~A}$ tolerating "us" and a tolerated "them" is implicit in the idea of toleration as a response to difference. Legal toleration closely aligns that "us" with the authority and power of the state. Furthermore, the invocation of toleration also always conjures up its limits. Toleration is a kind of ad hoc response to difference - I might be moved or required to tolerate this point of disagreement or difference but find the next intolerable. The limits of legal toleration tend to faithfully trace the cultural assumptions that ground liberal constitutional culture. ${ }^{69}$ Finally, and most notable in its contrast with neutrality, toleration concedes - indeed, it proceeds from - the existence of a normative position on the side of the tolerator. Otherwise put, when applied in response to religious difference, legal toleration admits that the

\footnotetext{
${ }^{65}$ For Canadian examples, see e.g. Chamberlain v Surrey School District No 36, [2002] 4 SCR 710 at para 21; Multani, supra note 35 at para 76.

${ }^{66}$ Writing in 2005, Bruce Ryder notes that the concept of neutrality has historically played a less important role in Canada than is has in the U.S.: "State Neutrality and Freedom of Conscience and Religion," Supreme Court Law Review (2d) 29(2005): 170-71. Although the concept retains different connotations in the two constitutional histories, "neutrality" plays a much more prominent role in the Supreme Court of Canada's recent religion jurisprudence. Research conducted by the author and Geneviève Murray (JD, NYU / Osgoode) reveals that, since 2004, the Court's invocation of the concept of "toleration" has dropped off notably, with a suggestive increase in references to "neutrality," spiking in 2012 with the SL decision.

${ }^{67} \mathrm{SL}$, at para 10.

${ }^{68}$ Wendy Brown, Regulating Aversion: Tolerance in the Age of Identity and Empire (Princeton and Oxford: Princeton University Press, 2006).

${ }^{69}$ Benjamin L. Berger, "The Cultural Limits of Legal Tolerance," Can. J. L. E Jur. 21, no. 2 (2008).
} 
legal system embodies and expresses a set of commitments and judgments about a good life - concedes its non-neutrality - but counsels acceptance of certain departures from the norm in the name of political peace, mutual respect, or other strategic or moral ends.

Viewed in that light, it ought not to be surprising that neutrality has become so attractive in modern legal secularism. In a society of comparative religious homogeneity and unabashed confessional partiality - the kind of conditions out of which the concept emerged ${ }^{70}$ - toleration may have been a relatively satisfying response. In a modern context of deep normative pluralism, however, the politics and partiality implicit in toleration can prove troublesome. Neutrality seems to offer more. A principle of state neutrality speaks to the evenhandedness necessary in a religiously and culturally plural society. Furthermore, in Canada as elsewhere, the concept of state neutrality appealingly maps political instincts that focus on equality as the nonpareil political virtue (although there is a risk that embracing an unsophisticated conception of neutrality can unseat the idea that substantive equality sometimes demands practices of differential treatment and recognition). But most importantly, use of the concept of state neutrality better effaces the power dynamics involved in the management of religious diversity. It rhetorically positions law outside of the "us" and "them" of political conflict; it casts law in the role of disinterested conciliator rather than boundary-setter; and its invocation relieves the legal system of the burden of its own cultural and historical contingency. With this, language of neutrality appeals to a powerful myth that underwrites contemporary law. The conceit of autonomy upon which modern liberal legal orders lean for their political authority works by depoliticizing law's rule sufficiently to attract broad assent. ${ }^{71}$ Comaroff and Comaroff perceptively describe the seductiveness of law's neutrality amidst the complexities of modern political life:

the language of legality offers an ostensibly - note, ostensibly - neutral register for communication across lines of social and cultural cleavage, making it possible to equate unlike values, to authorize hybrid collaborations, and to adjudicate

\footnotetext{
${ }^{70}$ See Perez Zagorin, How the Idea of Religious Toleration Came to the West (Princeton and Oxford: Princeton University Press, 2003).

${ }^{71}$ Courtney Bender and Pamela E. Klassen, eds., After Pluralism: Reimagining Religious Engagement (New York: Columbia University Press, 2010); Brown, Regulating Aversion: Tolerance in the Age of Identity and Empire. This was, of course, precisely Rawls' ambition in his work on public reason and political liberalism: John Rawls, Political Liberalism (New York: Columbia University Press, 1996).
} 
impossibly contradictory claims. The pragmatic promise of jural instruments is that they have the capacity to create equivalence amidst contrast, providing a currency that appears to allow for the transaction of incommensurable interests across otherwise intransitive borders. Thus it is that law offers a common denominator, and a means of imposing coherence, in socially and ethically incoherent circumstances. ${ }^{72}$

The same process of depoliticization and ambition for coherence helps to explain the attractiveness of an organizing principle of state neutrality when specific attention is turned to problems of religious diversity. Consider, for example, the following passage from Justice Deschamps' dissenting opinion in Bruker $v$ Marcovitz, a passage in which the very essence of Canada's commitment to religious freedom and multiculturalism turns out to be a guarantee of neutrality, a guarantee that underwrites the legitimacy of law under conditions of religious diversity:

Canada's adoption of multiculturalism and attachment to the fundamental values of freedom of conscience and religion and of the right to equality guarantee to all Canadians that the courts will remain neutral where religious precepts are concerned. This neutrality gives the courts the legitimacy they need to play their role as arbiters in relation to the cohabitation of different religions and enables them to decide how to reconcile conflicting rights. ${ }^{73}$

This is a fine expression of the typical imaginative tethering of law's legitimacy to the depoliticizing effects of the concept of neutrality. Neutrality is a more comforting, less politicized standard under which to march in a landscape of considerable normative difference.

Whatever the reason for the concept's ascendance, its current appeal and influence seems uncontroversial. And, to be sure, substantial political goods can be achieved guided by a commitment to state neutrality and evenhandedness in the treatment of religion. A demand for neutrality imposes a welcome discipline on government to carefully consider the ways in which its actions may unjustifiably favor one religion or impose burdens on another. It also counsels caution about installing any particular metaphysical views - including agnosticism or atheism - as

\footnotetext{
${ }^{72}$ Jean Comaroff and John L. Comaroff, Theory from the South: Or, How Euro-America Is Evolving toward Africa (Boulder and London: Paradigm Publishers, 2012) 145.

${ }^{73}$ Bruker v Marcovitz, [2007] 3 SCR 607, at para 102.
} 
a de facto state religion. But a case like SL suggests a risk of slippage or concept creep in the use of this orienting idea. In the hands of some, the requirement for neutrality can expand to suggest that any position-taking on the part of the state, the pursuit of any vision of a good society, is a mischief. Issues of religion and education, viewed and understood in the frame that I have presented them, point to a distinction worthy of identification and commanding attention within the concept of state neutrality.

The crucial conceptual distinction is this: the state must be neutral in its treatment of religion; it need not, however, be neutral about the nature of a good society. ${ }^{74}$ Though its demand for evenhandedness in the state treatment of various religions - as well as non-religion and religion is noble and sound, what state neutrality should not be heard to demand is the state's indifference to the conditions for a healthy civic life. Maclure and Taylor share this sense of what state neutrality demands, casting the point in terms of "constitutive values":

A liberal and democratic state cannot remain indifferent to certain core principles, such as human dignity, basic human rights, and popular sovereignty. These are the constitutive values of liberal and democratic political systems; they provide these systems with their foundations and aims. ${ }^{75}$

\begin{abstract}
Although equality of state treatment in matters of religion must be assiduously pursued, the demand for state neutrality should not expand to require the state to resile from the pursuit of the conditions necessary for a just and ethical common world. To concede more to the concept of state neutrality invites an unreflective libertarianism, confusing the neutral state with an inert state, a public life not permitted to act in the interests of its own flourishing. To claim otherwise is to posit a wholly bureaucratic state - a governance structure, not a polity. State action that defends and promotes the principles and aims of a democracy characterized by freedom, equality, and respect for difference does not thereby offend the principle of state neutrality in matters of religion.

\footnotetext{
${ }^{74}$ Ryder, commenting on Justice LeBel's dissenting reasons in Congrégation des témoins de Jéhovah de St-Jérôme-Lafontaine v Lafontaine (Village), [2004] 2 SCR 650, draws a different distinction within the concept of neutrality, that of neutrality between religions as against neutrality about religion (supra, note 66). Ryder argues that the Canadian tradition supports the state's affirmative valuation of religion and that "[ $t]$ he state's duty of neutrality between religions, in Canadian law.... permits the state to promote, in an evenhanded manner, a religiously-positive pluralism" ("State Neutrality and Freedom of Conscience and Religion," 185.).

${ }^{75}$ Maclure and Taylor, Secularism and Freedom of Conscience: 11.
} 
Of course it matters deeply how the state pursues such principles and aims. If inclusion and respect for diversity are democratic lodestars, any state action - including the design of state education - should itself be characterized by openness to multiple voices, various perspectives, and critical debate. One should expect modesty from state institutions, recognizing that family, community, and culture can be important sources of insight and meaning for individuals and ethical resources for society as a whole. That is, indeed, one of the strengths of a pluralist democracy. And one would be right to demand due appreciation for the depth of the claims involved in matters of religious difference, of the complex ways that cultural communities are constituted, and attention to the needs of such communities. But so long as those features are in place, the concept of state neutrality is not incommensurable with a principled defence of the needs and conditions of a just political community. Courts play an important role in insisting on those features and ensuring evenhanded treatment of religion. Yet freed from the burden of a too-capacious conception of state neutrality, they can also play the crucial role of clearly articulating, for continued assessment and debate, the principles and demands of a pluralist democracy.

The "crisis" with which Arendt was so concerned was a crisis of responsibility. Faced with the many intense interests that constellate around education in the context of a religiously diverse society, invocation of the idea of neutrality cannot relieve us of the burdens of this responsibility. Neutrality in education cannot suggest that the state stand inactive when conscious of the need to ensure the continuance of a common social world, and mindful of the interests of children, whose autonomy and identity cannot be neatly folded into that of their parents. State neutrality in matters of religion does not compel a society agnostic as to its own value, health, and needs, nor to the freedom of the children who will be charged with sustaining it. 